\title{
Drivers of the Technology Adoption In Healthcare
}

\author{
Juliana Pascualote Lemos de Almeida ${ }^{\dagger}$ \\ Universidade de Brasilia (UNB) \\ Josivania Silva Farias ${ }^{\omega}$ \\ Universidade de Brasilia (UNB) \\ Hervaldo Sampaio Carvalho ${ }^{¥}$ \\ Universidade de Brasilia (UNB)
}

\section{ABSTRACT}

This paper proposes a theoretical framework for the study of the diffusion of ICT in management and assistance services in healthcare and empirically verifies its applicability in studying adoption of technology in this area. There was a review of literature in the period 2004-2014. Based on this framework, the researchers verified empirically the applicability of organizational drivers proposed in the prior conditions, through a case study conducted by interviews with 13 managers of a Brazilian public hospital that is adopting a nursing prescription module. Through the content analysis, eight organizational drivers of the technology adoption were confirmed. For future research, it is relevant to verify the applicability of the organizational and individual drivers in the other phases of the framework organized according to Rogers (1983), as well as in the prior conditions, either by new case studies or by developing quantitative research instruments about the management process of technology adoption in organizations.

Keywords: Diffusion; ICT; Drivers; Hospitals; Case study.

\section{INTRODUCTION}

Diffusion is a process by which innovation is transmitted to the members of the social system through communication channels (ROGERS, 1983). The diffusion of innovations involves an important innovation decision process supported by the Innovation Diffusion Theory (IDT) originated by Rogers (1983). It seems to be about a sequential linear stage framework of the innovation decision-making process, which simplifies the complexity that may exist in the adoption of innovations. This phenomenon is a great challenge for healthcare organizations that are extremely complex (BARLOW, 2013). It is helpful to employ the same logic of innovation decision process to studies on Information and Communication Technologies (ICT) adoption in healthcare organizations.

The Information and Communication Technology is a linkage between telecommunications and computing technologies, which is able to improve work routines and is influenced by organizational, technological, economic and individual drivers (BOUWMAN et al., 2005). The studies on drivers that intervene the adoption of innovations are capable of making the decision-making processes more effective, both at an individual or at an organizational system level, through more effective political decisions.

\footnotetext{
Corresponding author:

† Universidade de Brasília (UNB)

E-mail: juliana.pascualote@gmail.com

$\Omega$ Universidade de Brasília (UNB)

E-mail: josivania@unb.br

${ }^{¥}$ Universidade de Brasília (UNB)

E-mail: hervaldo1@gmail.com

Received: 10/04/2015.

Revised: 12/04/2015.

Accepted: 03/02/2016.

Published Online: 02/01/2017.
} 
So, it is timely to study the drivers that intervene in the process of adopting ICT considering healthcare. On the one hand, the organizational perspective addresses all drivers related to the nature of the organization and to the environment in which it operates, and on the other hand, the individual perspective considers all drivers associated with the acceptance, the attitude, the intention, the propensity and readiness to use technology and the post adoption stage of the individual, as well as, drivers related to the users perception of technology (BOUWMAN et al., 2005).

The process proposed by Rogers (1983) is relevant to study diffusion of innovations and suitable to study its drivers, since it already demonstrates some intervening factors, running as a theoretical platform to incorporate more drivers. The contribution of this paper is to expand the literature about diffusion of technologies in healthcare, supporting and encouraging scholars and decision makers. Keeping in this view, this paper aims to outline a theoretical framework for the study of the diffusion of ICT in management and assistance services in healthcare and empirically verify, at least in part, the applicability of the proposed framework for adoption of technology in this area.

\section{DIFFUSION OF INNOVATION PROCESS}

From the IDT, Rogers (1983) deepened the understanding about diffusion of innovations (he sometimes used innovation as synonymous with technology) and developed the innovation decision process.

It is important to mention that the decisions and events prior to the first adoption of an innovation strongly affect the diffusion process and an innovation has five basic attributes (ROGERS, 1983. p. 15, 16): relative advantage: the degree to which an innovation is perceived as better than the idea it supersedes; compatibility: the degree to which an innovation is perceived as being consistent with the existing values, past experiences, and needs of potential adopters; complexity: the degree to which an innovation is perceived as difficult to understand and use; trialability: the degree to which an innovation may be experimented with on a limited basis; and observability: the degree to which the results of an innovation are visible to others.

The innovation diffusion process covers decisions, activities and impacts that come from needs or problems (ROGERS, 1983). In this process, the decision-making units strive to gain knowledge about an innovation to take an attitude towards it. Observing the initial conditions that affect the innovation decision process, Rogers (1983) gives four kinds of needs to the understanding of prior conditions, which includes the set of existing practices, the perceived needs and problems, the innovativeness, that is the degree to which an individual unit or another adoption unit is relatively incipient in adopting new ideas from other members of a system, and the social systems standards.

The process goes through five stages (ROGERS, 1983). The stage of knowledge happens when the decision-making unit is exposed to an existing innovation and understands how it works. It includes the characteristics of the decision-making units in relation to the socioeconomic aspects, personality variables and communication behavior. Persuasion happens when the decision-making unit forms a favorable or unfavorable attitude towards innovation. Perceived characteristics influence this stage. Decision happens when the decision-making unit creates efforts in activities that lead to the choice between the adoption and rejection of the innovation. Implementation happens when a decision-making unit puts into use a new idea. Rogers (1983) also mentions the reinvention, which is an innovation that undergoes changes made by its many adopters. Finally, confirmation happens when an individual seeks reinforcement to an innovation decision already made. 
The process also proves to be very useful for both theory and practice. However, the diffusion should not be fully understood (LATOUR, 2000). The diffusion process drawn is permeated by the organizational and individual drivers that will hinder or contribute to the success and fluidity of the process and its consolidation (ROGERS, 1983).

\section{THEORETICALAPPROACHES ON TECHNOLOGY ADOPTION}

From the 1960s until 2014, scholars have developed several studies with the intent of understanding the attitudes, the use intentions and the behavior towards the adoption of technologies. Seeking an explanation for the impact of the intentions on the individuals' behavior, two major theories have been developed, the Theory of Reasoned Action (TRA) by Fishbein and Ajzen (1975) and the Theory of Planned Behavior (TPB) by Ajzen (1985, 1991).

In 1986, Davis introduced the Technology Acceptance Model (TAM), aiming at the validation of measurement scales for two different constructs: perceived usefulness and ease of use, which mean, respectively, how much an individual believes that a system is useful for improving their performance at work and how much he believes that using a system would require less effort. The author dealt with the users' acceptance, linking the variables perceived usefulness and ease of use to the use intention and to behavior.

Davis, Bagozzi and Warshaw (1989) mentioned the importance of promoting a base to trace the impact of external drivers about beliefs, attitudes and internal intentions in the field of technologies acceptance, and measured the intentions, explaining them in terms of attitudes, subjective norms, perceived usefulness, perceived ease of use and related variables. The results of applying this model indicated $45 \%$ of variance in the use of intentions at the beginning of the analysis period and, after 14 weeks, the variance reached $57 \%$. The perceived usefulness explained more than a half of the intentions of the people, after 14 weeks.

In subsequent study, Davis (1989) reached an explanation around $40 \%$ of the variance in use and behavioral intention with TAM. Venkatesh and Davis (2000) proposed the TAM2, a new version of TAM, which incorporated new constructs social influence and cognitive instrumental processes, including subjective norms, voluntariness, image, job relevance perception, output quality and demonstrability of the result.

Later, Venkatesh et al. (2003) and Venkatesh, Thong and Xu (2012) developed an unified model, highlighting the important role of Venkatesh in the advancement of technology acceptance models. Parasuraman and Colby (2001) also contributed to the study of technology adoption, regarding the readiness of individuals. Ratchford and Barnhart (2012) addressed propensity of use, combining the evaluation of attitudes and beliefs of people who may or may not be users of technologies, using as analysis inhibiting and facilitating drivers.

Presenting the framework that will come as a partial result of this paper, the importance of all these authors and their studies mentioned hitherto will be verified, as presented in the Table 4. Among others, these authors are the precursors and main bases who encouraged further studies and therefore their seminal contribution was central in the framework formation.

\section{METHODOLOGY}

This research is a descriptive qualitative case study. Two main objectives are pursued in this paper conducted through specific methods. 
The proposed framework has as background the innovation decision process and suggests which drivers of the diffusion of ICT from the organizational and individual perspective are evident in each stage of this process, adding drivers besides those suggested originally by Rogers (1983), Davis (1989), Venkatesh and Davis (2000), Parasuraman and Colby (2001) and Venkatesh et al. (2003). It was necessary to identify the drivers proposed by subsequent studies by doing a literature review.

The literature review used the descriptors diffusion, adoption, acceptance, innovation, health/healthcare, hospital, information, technology and ICT. The searches were done using ProQuest database encompassing the Science and Technology, Social Sciences, and Health and Medicine areas. The selected databases were: ASSIA; ERIC; LISA; Social Services Abstracts; Sociological Abstracts; and Technology Research Database, taking into consideration the period between 2004 and 2014, a ten-year period. From 51 publications, 37 could be accessed and 21 were considered conducive to this research as they reveal drivers that were added in the diffusion stages to compose the framework.

Regarding the purpose of empirically verify the applicability of the framework in management and assistance services in healthcare, it was conducted a case study. The case study highlighted the organizational drivers in the "prior conditions" phase of the nursing prescription module adoption of a management application for the federal university hospitals (Aplicativo de Gestão para Hospitais Universitários Federais - AGHU) at the Hospital Universitário de Brasília (HUB). This hospital is a large one that offers the total of its services for free through the Unified Health System (SUS) located in the Brazilian Federal District, managed by Empresa Brasileira de Serviços Hospitalares (Ebserh) an organization which manages federal university hospitals, under the Brazilian Ministry of Education. The nursing prescription module is being implemented in the HUB. It is not present in the entire hospital, only in some areas such as Emergency Unit.

Thus, the researchers conducted interviews using a semi-structured script directed to 13 managers involved in the decision making process of adopting the module, making sure professional data of respondents and organizational drivers involved in the prior conditions of decision-making process. The script contained questions based on the categories proposed in the prior conditions of Rogers process (1983). The application of this instrument occurred after approval by the Ethics Committee of the School of Medicine and School of Nursing at the University of Brasilia (UnB), and by willingness of individuals, proved by the Term of Consent. Telephone contacts were made and e-mails were sent inviting the hospital managers for this study. The researchers conducted 13 interviews, in the period May-September 2015, according to the availability of the participants that make up the top management, the IT management and the managers of several nursing sectors at the hospital. Table 1 presents the subjects acronyms used in this study and their general function.

For data analysis, there was content analysis with a priori categorization, because the aim was to identify in the statements, organizational drivers set out in the framework prior conditions (BARDIN, 2011). Table 2 presents the symbols and formats used as transcription conventions as suggested by Bauer e Gaskell (2008).

\section{THEORETICAL REFERENCE: DRIVERS OF TECHNOLOGY ADOPTION IN HEALTHCARE}

For the diffusion of technological innovations in healthcare and hospital services, it is essential to know the key values that the technologies are able to create, which are the disease prevention, the ease of suffering and the improvement of the 
Table 1. Subjects acronyms

\begin{tabular}{llllll}
\hline$\#$ & Acronyms & General function & $\#$ & Acronyms & General function \\
\hline 1 & SM1 & Strategic manager & 8 & CNR3 & Chief Nursing Routine \\
2 & SM2 & Strategic Manager Nursing & 9 & CNR4 & Chief Nursing Routine \\
3 & SITM1 & Strategic IT Manager & 10 & CNR5 & Chief Nursing Routine \\
4 & SITM2 & Strategic IT Manager & 11 & CNR6 & Chief Nursing Routine \\
5 & CCU1 & Chief Care Unit & 12 & CNR7 & Chief Nursing Routine \\
6 & CNR1 & Chief Nursing Routine & 13 & CNR8 & Chief Nursing Routine \\
7 & CNR2 & Chief Nursing Routine & & & \\
\hline
\end{tabular}

Table 2. Transcription conventions

\begin{tabular}{lc}
\hline Symbols or formats & Meaning \\
\hline$(-)$ & Uncertain stretch suppressed \\
$(\ldots)$ & Stretch suppressed \\
Italics & Word or stretch written in colloquial language or grammatical error \\
{$[$ Bracketed word $]$} & Explanations of the researchers \\
\hline
\end{tabular}

quality of life of people who seek some kind of treatment, according to Ghodeswar and Vaidyanathan (2006). In line with this, a Health Information Technology (HIT) is able to change healthcare services, because it involves data processing at a hardware and software level to store and share information that supports the decision (THOMPSON; BRAILER, 2004, KIM; PARK, 2012).

It is important to highlight that Ward et al. (2007) reviewed the literature on the drivers that impact the attitudes related to the technologies in health services and verified that the Health Care Practitioners (HCPs) are important for the acceptance and use of technologies. Therefore, Ward et al. (2007) stressed that there is a gap in the study of this subject, which is little exploration of the driver 'change of attitudes' of the HCPs regarding the adoption of technologies.

Chen et al. (2008) aimed to verify the behavior intention of nurses tied to public health (Public Health Nurses - PHNS) in relation to web-based learning in pre-implementation stage. They also aimed to identify the nurses' drivers, based on TAM by means of a 202 nurse's sample. Chen et al. (2008) noticed great chances of technology adoption. Moreover, they found that perceived usefulness is the driver that most directly affects the behavior intention, which is indirectly influenced by the drivers: perceived ease of use, individual's computer competency and Internet access at workplaces. All these drivers have a positive effect for a greater behavior intention, in the nurses' case.

Focusing on individual perceptions, Aggelidis and Chatzoglou (2009) set out to develop and test a modified version of the TAM model and they considered other models presented in the literature based on the Hospital Information Systems (HIS). On the main data collection phase, 341 users of these systems from the main public hospitals of the East Macedonia and Thrace region answered the survey. The results showed that perceived usefulness, ease of use, social influence, attitude, facilitating conditions, self-efficacy (individuals with higher self-efficacy are more likely to experience positive effects than individuals with lower self-efficacy) and, indirectly, training, significantly impact the behavior intention of the people in accepting technologies in healthcare organizations. 
Holden and Karsh (2009) conducted a literature review on the adoption of HIT to ascertain whether the use of existing theories to develop testable models of HITs benefited both research and practice and found that this is true. Specifically, they found that ease of use (or usability) may be the result of HIT that fits with user abilities and task requirements. To achieve it: adjustments can be made to the HIT interface to make it more user friendly by building in help features or by making design more consistent with clinicians' mental models; clinicians can be provided with more training or time to practice using the system, perhaps in a separate room used for carrying out HIT emulation; or the task can be redesigned in any number of ways.

Kijsanayotin, Pannarunothai and Speedie (2009), stating the relevance of the acceptance and use HIT in community health centers of Thailand, applied the UTAUT model in order to test and confirm drivers involved in the adoption of this technology. Through surveys administered in 12 Thailand provinces, with 1,607 Community Health Centers (CHCs), they found out that individuals who worked in the health centers showed a high level of acceptance and use of the technology. Kijsanayotin, Pannarunothai and Speedie (2009) confirmed that the drivers performance expectance, effort expectance, social influence, voluntariness, previous experiences with technology, intention of use and facilitating conditions are able to predict the acceptance and use of a health IT system in community health centers.

According to Holden and Karsh (2010), the growing interest in the reactions, behaviors and attitudes of technologies users in healthcare indicated the importance of theories focused on technology acceptance, use, readiness, propensity, among others. These authors conducted a literature review of 16 data sets analyzed in over 20 health clinical studies. In relation to the application of the TAM, these authors decided to evaluate the future of the TAM applied to health services based on its past. The results showed that the model is able to predict a considerable part of the acceptance of technologies in healthcare, and that the theory can generate benefits to the original model, either through its amendment or extension.

Hung et al. (2010) proposed and tested an integrated model that incorporates organizational and technological or systemic drivers as key determinants of the adoption, in healthcare institutions, of the Customer Relationship Management System (CRMS), an ICT that makes the process of establishing, developing and maintaining the relationships with customers in medical centers, regional hospitals and community hospitals, easier. Through carrying out a series of surveys in medical centers, regional hospitals and community hospitals in Taiwan, those authors found out that the attributes: hospital size, the system capabilities of staff, innovation of senior executives (senior executives are the critical people in determining the organizational attitude towards innovation, so, their ability, preferences and readiness to change are critical to the innovation decision), knowledge management capabilities, and relative advantage, have significant influence on the CRMS adoption.

Alkraiji, Jackson and Murray (2011) studied the technology adoption process (HIT) in Saudi Arabia and exposed drivers that affect this phenomenon as follows: network externalities related with communication channels; external pressure of the government; integration of system with the existing ones; accreditation of technology adoption; standards benefits; organization characteristics - organization size, otype, structure, culture and complexity; the degree of politics in the organization and the degree of bureaucracy in the organization; policy and procedures; clinician engagement; standards cost; and external support.

Emani et al. (2012) conducted a survey with 760 patients in order to apply the innovation diffusion process for the study of the Personal Health Records (PHRs) technology, this way, they tested and confirmed several predictors of the value of this 
HIT, namely: relative advantage, ease of use, trialability, perceptions of privacy and security, age and computer use. Emani et al. (2012) concluded that the innovation diffusion process fits in the PHR perception study and provides an appropriate basis to identify drivers that distinguish PHR users from non-users.

Ketikidis, Dimitrovski and Bath (2012) also tested the TAM model with some new proposals in order to investigate the beliefs and acceptance of the HIT with health professionals. Ketikidis Dimitrovski and Bath (2012) conducted 133 valid interviews with doctors and nurses from three clinics of the city of Skopje, Republic of Macedonia, in order to evaluate the intention of use of HIT predictors and found that ease of use, relevance norms and subjective norms could directly predict the intention of use of this technology.

Kim and Park (2012) developed and tested a model about behavior intention and health behavior of various HIT consumers. This model is an extension of the TAM. Kim and Park (2012) interviewed 728 members of the three largest online health portals in South Korea and, based on the results, categorized drivers that affect the behavior intention for measurement, storage and healthcare data management, in the health zone, in the information zone and in the technology zone. The first one is processed from the health status to perceived threat, perceived usefulness, attitude and behavioral intention. In the information zone, the driver is the perceived usefulness, which gets subjective norms influences. Finally, in relation to the technology zone, it has technology use forms, technology reliability, output quality and result demonstrability, which affect the perceived usefulness.

Lin, Lin and Roan (2012) set out to investigate the physicians' reactions to the electronic medical record with emphasis on managerial issues, specifically regarding the barriers, threats and inequality, all of them perceived in relation to technology. 115 physicians from six different hospitals were interviewed and the results revealed that a perceived threat directly and negatively affects the usefulness and the behavioral intention. The Perceived inequity has a direct and positive effect on the perceived threat and a negative effect on the perceived usefulness, and an indirect impact on the behavioral intention.

Vasileiou, Barnett and Young (2012) conducted in-depth interviews with 18 main informants of 15 successful innovations in health services in the UK, innovations awarded by the Health Service Journal, with the aim of studying the usefulness of the innovations in health services. The results showed that the innovators articulated concepts related to the main existing in the British National Health Service approaches: clinical trials and improvement cycles. Vasileiou, Barnett and Young (2012) found out that health services need individuals who have technical knowledge.

Cresswell and Sheikh (2013) state that the diffusion and the adoption of technologies in healthcare reveal many difficulties related to the diversity of technical, social and organizational drivers. They contributed with a description of the main results on each of the three drivers. They also observed some gaps in the currently developed research on technologies diffusion, which need to be investigated in the future: environmental influences, connection between adopters and organizational attributes; and noticed that the final users are not opposed to the technologies, but resist their use. Cresswell and Sheikh (2013) gathered information found in several studies published among 1997 to 2010, as provided in Table 3.

Marsan and Paré (2013) researched the antecedents of the decisions to adopt OSS (Open Source System) in healthcare organizations. Through 18 semi-structured interviews with IT experts from the health and social services sector in the Province of Quebec, Canada, Marsan and Paré (2013) found eight drivers that influence the adoption of this technology, grouped as follows: software characteristics (low cost, 
Table 3. Determinant drivers that influence innovation diffusion or adoption

\begin{tabular}{ll}
\hline Drivers & Descriptions and references \\
\hline Technical & $\begin{array}{l}\text { Early demonstrable benefits; perceived ease of use; costs; the extent to which a system } \\
\text { is interoperable with existing technology; the extent to which technology fits in with } \\
\text { existing organizational processes; and the extent to which it can be trialled. }\end{array}$ \\
\hline & $\begin{array}{l}\text { Information technology literacy and general competencies of users; personal and peer } \\
\text { attitudes toward an innovation; financial considerations; the extent to which the tech- } \\
\text { Social }\end{array}$ \\
& $\begin{array}{l}\text { nology supports inter-professional roles and working; on-going involvement of key } \\
\text { stakeholders (management, developers and users) at the conception and design stages; }\end{array}$ \\
& and opportunity for field testing of early prototypes and open communication channels. \\
\hline \multirow{2}{*}{ Organizational } & $\begin{array}{l}\text { Organizational leadership; and Support to boundary spanning and reduction of the gulfs } \\
\text { between technology, users, managers and clinicians. }\end{array}$
\end{tabular}

Source: Organized by Cresswell and Sheikh $(2013,76,81)$

right to use and compatibility with organizational needs); characteristics of organizations to absorb Open Source System (internal IT resources availability and internal expertise in open source software); and characteristics of external environment in relation to institutional pressures and public discourse about OSS (external expertise in OSS, vision and leadership by departmental authorities with regard to software adoption, community interest and clarity, consistency and richness of the OOS public discourse).

Hung, Tsai and Chuang (2014) studied nurses' use behavior of the Primary Health Information System (PHIS) technology, which supports primary health care with the ability to improve the practice and delivery of healthcare services quality. Through the application of 768 questionnaires with primary healthcare nurses, they found that the compatibility driver has a positive impact on the perceived usefulness and trust in relation to the ICT. Hung, Tsai and Chuang (2014) studied got to the conclusion that if the nurses see the technology as reliable, they become more prone to the perceived usefulness and, with this, it is possible to establish a favorable attitude.

Lai, Lin and Tseng (2014) identified determinants in the adoption of the Radio Frequency Identification (RFID), a technology that performs automatic data collection and tracking of assets and people, including in hospital services. In a sample of 102 hospitals, the authors found that cost; ubiquity that is the capacity to transmit communicate, monitor, and control signals to individuals or objects to perform various functions, regardless of users' whereabouts (LAI; LIN; TSENG, 2014, p. 5); compatibility ; security and privacy risk; top management support; hospital scale, large-scale hospitals are more likely to adopt innovative technology than the small ones, according to Chang et al. (2007); financial readiness, installation costs, implementation and maintenance (KIM; GARRISON, 2010); and government policy, government's financial support, training curriculum, specification and policy stability, according to Chang et al. (2006); are the most impactful drivers in the adoption of RFID.

\section{RESULTS AND DISCUSSION}

\subsection{THEORETICAL FRAMEWORK PROPOSAL}

In view of the studies reviewed previously, we found organizational and individual drivers. From reflexive and interpretive analysis, those groups of drivers were organized on the decision process of diffusion of innovations, proposing the theoretical framework shown in the Table 4. The drivers proposed by Rogers (1983) were 
Table 4. Framework with organizational and individual drivers distributed in the decision process stages proposed by Rogers (1983)

\begin{tabular}{|c|c|c|c|c|c|}
\hline Prior Conditions & Knowledge & Persuasion & Decision & Implementation & Confirmation \\
\hline $\begin{array}{l}\text { Organizational } \\
\text { drivers: }\end{array}$ & Organizational drivers: & Organizational drivers: & $\begin{array}{l}\text { Organizational } \\
\text { drivers: }\end{array}$ & Organizational drivers: & $\begin{array}{l}\text { Organizational } \\
\text { drivers: }\end{array}$ \\
\hline $\begin{array}{l}\text { Availability of } \\
\text { resources }\end{array}$ & $\begin{array}{l}\text { Clarity, consistency and } \\
\text { richness of technology }\end{array}$ & Clinician engagement & $\begin{array}{l}\text { Communication } \\
\text { channels }\end{array}$ & $\begin{array}{l}\text { Communication chan- } \\
\text { nels }\end{array}$ & $\begin{array}{l}\text { Communication } \\
\text { channels }\end{array}$ \\
\hline $\begin{array}{l}\text { Communication } \\
\text { channels }\end{array}$ & Communication channels & $\begin{array}{l}\text { Communication chan- } \\
\text { nels }\end{array}$ & $\begin{array}{l}\text { Stakeholder } \\
\text { involvement }\end{array}$ & $\begin{array}{l}\text { Support to boundary } \\
\text { spanning }\end{array}$ & $\begin{array}{l}\text { Stakeholder } \\
\text { involvement }\end{array}$ \\
\hline External expertise & $\begin{array}{l}\text { Compatibility with organi- } \\
\text { zational needs }\end{array}$ & $\begin{array}{l}\text { Community interest in } \\
\text { technology }\end{array}$ & $\begin{array}{l}\text { Support to boun- } \\
\text { dary spanning }\end{array}$ & $\begin{array}{l}\text { Technology customi- } \\
\text { zation }\end{array}$ & $\begin{array}{l}\text { Support to boun- } \\
\text { dary spanning }\end{array}$ \\
\hline $\begin{array}{l}\text { External pressure } \\
\text { of the government }\end{array}$ & Integration of system & $\begin{array}{l}\text { Vision and leadership } \\
\text { by departmental autho- } \\
\text { rities with technology } \\
\text { adoption }\end{array}$ & $\begin{array}{l}\text { Vision and } \\
\text { leadership by } \\
\text { departmental } \\
\text { authorities with } \\
\text { technology } \\
\text { adoption }\end{array}$ & $\begin{array}{l}\text { Stakeholder involve- } \\
\text { ment }\end{array}$ & $\begin{array}{l}\text { Technology } \\
\text { adoption accredi- } \\
\text { tation }\end{array}$ \\
\hline $\begin{array}{l}\text { External support } \\
\text { in case of com- } \\
\text { plexity }\end{array}$ & $\begin{array}{l}\text { Interoperability conside- } \\
\text { rations }\end{array}$ & $\begin{array}{l}\text { Stakeholder involve- } \\
\text { ment }\end{array}$ & $\begin{array}{l}\text { Individual dri- } \\
\text { vers: }\end{array}$ & $\begin{array}{l}\text { Training or time to } \\
\text { practice using the } \\
\text { system }\end{array}$ & $\begin{array}{l}\text { Individual dri- } \\
\text { vers: }\end{array}$ \\
\hline $\begin{array}{l}\text { Facilitating con- } \\
\text { ditions }\end{array}$ & $\begin{array}{l}\text { Direct and indirect costs } \\
\text { involved }\end{array}$ & $\begin{array}{l}\text { Support to boundary } \\
\text { spanning }\end{array}$ & Attitudes & Individual drivers: & Attitudes \\
\hline $\begin{array}{l}\text { Felt needs/pro- } \\
\text { blems }\end{array}$ & $\begin{array}{l}\text { Demonstrability of the } \\
\text { results }\end{array}$ & $\begin{array}{l}\text { Top management } \\
\text { support }\end{array}$ & $\begin{array}{l}\text { Behavioral } \\
\text { intention }\end{array}$ & Age & $\begin{array}{l}\text { Output quality } \\
\text { Perceived use- } \\
\text { fulness }\end{array}$ \\
\hline $\begin{array}{l}\text { Government } \\
\text { policy }\end{array}$ & $\begin{array}{l}\text { Reduction of the distance } \\
\text { between technology, users } \\
\text { and managers }\end{array}$ & Individual drivers: & Effort expectance & Attitudes & $\begin{array}{l}\text { Perceived as } \\
\text { appropriate } \\
\text { technology }\end{array}$ \\
\hline $\begin{array}{l}\text { Innovation of } \\
\text { senior executives }\end{array}$ & Right of use & Attitudes & $\begin{array}{l}\text { Job relevance } \\
\text { perception }\end{array}$ & Gender & $\begin{array}{l}\text { Perceived ease } \\
\text { of use }\end{array}$ \\
\hline Innovativeness & Security and privacy risk & Behavioral intention & Optimism & Habits & $\begin{array}{l}\text { Perceived ine- } \\
\text { quity }\end{array}$ \\
\hline Internal expertise & $\begin{array}{l}\text { Social economic charac- } \\
\text { teristics }\end{array}$ & Effort expectance & $\begin{array}{l}\text { Performance } \\
\text { expectance }\end{array}$ & Hedonic motivation & $\begin{array}{l}\text { Perceived price } \\
\text { value }\end{array}$ \\
\hline $\begin{array}{l}\text { Internal IT re- } \\
\text { sources availa- } \\
\text { bility }\end{array}$ & Stakeholder involvement & $\begin{array}{l}\text { Job relevance percep- } \\
\text { tion }\end{array}$ & $\begin{array}{l}\text { Personal and } \\
\text { peer attitudes } \\
\text { toward an inno- } \\
\text { vation }\end{array}$ & $\begin{array}{l}\text { Image or status in use } \\
\text { of innovation }\end{array}$ & $\begin{array}{l}\text { Perceived relia- } \\
\text { bility }\end{array}$ \\
\hline Internet access & Standards benefits & Optimism & $\begin{array}{l}\text { Views and } \\
\text { beliefs of execu- } \\
\text { tives enablers of } \\
\text { adopting techno- } \\
\text { logies }\end{array}$ & $\begin{array}{l}\text { Individual's compe- } \\
\text { tency }\end{array}$ & Perceived threat \\
\hline $\begin{array}{l}\text { Knowledge ma- } \\
\text { nagement capa- } \\
\text { bilities }\end{array}$ & $\begin{array}{l}\text { Standards cost (direct and } \\
\text { indirect) }\end{array}$ & $\begin{array}{l}\text { Personal and peer } \\
\text { attitudes toward an } \\
\text { innovation }\end{array}$ & Vulnerability & Intention of use & $\begin{array}{l}\text { Personal and peer } \\
\text { attitudes toward } \\
\text { an innovation }\end{array}$ \\
\hline $\begin{array}{l}\text { Level of patient } \\
\text { demand }\end{array}$ & $\begin{array}{l}\text { Support to boundary span- } \\
\text { ning }\end{array}$ & $\begin{array}{l}\text { Views and beliefs of } \\
\text { executives enablers of } \\
\text { adopting technologies }\end{array}$ & & $\begin{array}{l}\text { Perceived as appropria- } \\
\text { te technology }\end{array}$ & $\begin{array}{l}\text { Proficiency in use } \\
\text { of technology }\end{array}$ \\
\hline $\begin{array}{l}\text { Network externa- } \\
\text { lities }\end{array}$ & System capabilities of staff & Vulnerability & & Perceived ease of use & Social influence \\
\hline $\begin{array}{l}\text { Norms of the } \\
\text { social system }\end{array}$ & $\begin{array}{l}\text { Technology fits in with } \\
\text { existing organizational } \\
\text { processes }\end{array}$ & & & Perceived inequity & $\begin{array}{l}\text { Subjective and } \\
\text { relevance norms }\end{array}$ \\
\hline $\begin{array}{l}\text { Organizational } \\
\text { policy and proce- } \\
\text { dures }\end{array}$ & $\begin{array}{l}\text { The extent to which the } \\
\text { technology supports inter- } \\
\text {-professional roles }\end{array}$ & & & Perceived price value & \\
\hline $\begin{array}{l}\text { Organizational } \\
\text { ability to rein- } \\
\text { vention }\end{array}$ & Risk level & & & $\begin{array}{l}\text { Perceived privacy and } \\
\text { security Perceived } \\
\text { Usefulness }\end{array}$ & \\
\hline $\begin{array}{l}\text { Organizational } \\
\text { and financial } \\
\text { readiness }\end{array}$ & Ubiquity & & & Perceived reliability & \\
\hline $\begin{array}{l}\text { Organizational } \\
\text { leadership }\end{array}$ & Individual drivers: & & & Perceived threat & \\
\hline
\end{tabular}




\begin{tabular}{|c|c|c|}
\hline $\begin{array}{l}\text { Organizational } \\
\text { learning, climate } \\
\text { and attitude }\end{array}$ & Attitudes & $\begin{array}{l}\text { Personal and peer } \\
\text { attitudes toward an } \\
\text { innovation }\end{array}$ \\
\hline $\begin{array}{l}\text { Organizational } \\
\text { size }\end{array}$ & $\begin{array}{l}\text { Personal and peer attitudes } \\
\text { toward an innovation }\end{array}$ & $\begin{array}{l}\text { Proficiency in use of } \\
\text { technology }\end{array}$ \\
\hline Previous practice & Personality variables & Self-efficacy \\
\hline $\begin{array}{l}\text { Individual dri- } \\
\text { vers: }\end{array}$ & Technical knowledge & Social influence \\
\hline $\begin{array}{l}\text { Attitudes Com- } \\
\text { munication beha- } \\
\text { viour }\end{array}$ & $\begin{array}{l}\text { Technological compatibility, } \\
\text { complexity, observability, } \\
\text { relative advantage and } \\
\text { trialability }\end{array}$ & $\begin{array}{l}\text { Subjective and relevan- } \\
\text { ce norms }\end{array}$ \\
\hline $\begin{array}{l}\text { Comfort to use } \\
\text { technology De- } \\
\text { pendence to use } \\
\text { technology }\end{array}$ & Use forms & $\begin{array}{l}\text { Views and beliefs of } \\
\text { executives enablers of } \\
\text { adopting technologies }\end{array}$ \\
\hline $\begin{array}{l}\text { Previous expe- } \\
\text { rience with tech- } \\
\text { nology }\end{array}$ & & Voluntariness of use \\
\hline Use of computer & & \\
\hline
\end{tabular}

kept according to the original framework and the others were logically distributed to the most appropriate stages of the process according to the literature.

The set of influencing drivers of the diffusion of technologies reported shows the strength of the Innovation Diffusion Theory (ROGERS, 1983), as well as of the studies of Davis (1989) and Venkatesh and Davis (2000), Venkatesh et al. (2003) and Venkatesh, Thong and $\mathrm{Xu}$ (2012), considering its effect on the great amount of research discussed. The most cited drivers still have a strong connection to those proposed by Rogers (1983) and the perceived usefulness (DAVIS, 1989, VENKATESH; DAVIS, 2000). Many studies still test, modify and confirm the findings of these authors. Holden and Karsh (2010) noticed the importance of the theory in generating benefits to the TAM.

The consolidation of the influencing drivers of the diffusion and adoption of technologies in management and assistance services in healthcare made it possible to see that some of them like external pressure of the government, community interest in technology, government policy and social economic characteristics are not part of the internal environment of the adopting organization, but make up its macro environment, surpassing the level of the firm. Cresswell and Sheikh (2013) suggested the study of the environmental influences as a gap in the research on diffusion of innovation. Reflecting on the organizational perspective proposed by Bouwman et al. (2005) it is noticed that it is important to consider exogenous drivers in coming studies.

An interesting proposition would be to consider the individual alignment of the decision makers and users to the innovation, i.e. to promote a change in attitudes according to the needs of the process and technology (WARD et al., 2007). The attitudes make up a very important driver cited in several reported studies and in the framework, they pervade all stages of the decision making process of Rogers (1983).

\subsection{FRAMEWORK APPLICABILITY: ORGANIZATIONAL DRIVERS IN PRIOR CONDITIONS}

The prior conditions include the practices adopted previously to start the decisionmaking process of diffusion, the existing problems and needs, the degree of innovativeness and the norms of the social systems (ROGERS, 1983). Before the adoption of the module in the HUB, the process of nursing prescription was not present in the practices of all the hospital sectors and the nursing care control was crude. Furthermore, there was no computerization of the process. On this, the CCU1 said: 
BBR

14,3

'At that time, (...) it was very precarious, (...) there was no system, nothing was computerized'.

Moreover, in some sectors, the Systematization of Nursing Assistance (SNA) was fragmented and nursing care disorganized. In other sectors, it did not even the nursing process was formal, that is the care was provided, but there was no documentation to prove the existence of nursing routines, as stated by CNR6:

'It was informal. The care was provided, but there was not a formalization of that'.

In addition, everything was done on paper, which leads to waste of time and rework possibilities. As a result, there was a difficulty in monitoring related to reading of manuscripts. In this regard, the SITM2 and CNR5 declared, respectively:

'It was everything on paper. (...) There were some problems. (...) In addition to wasting time, (...) sometimes you do not understand what is written'.

'There were situations that we manually prepared, when after looking in the patient's record, it was not. Someone took, someone threw away, someone just took off and did not return'

It was evident also that the routines of the nursing process were not mapped in the sectors, without, therefore, standardization and minimum requirements associated with this process. In most sectors, where this process has occurred, it happened at random and poorly oriented to the real needs of the patients, precisely because there was no standard and no control mechanisms. In the scenario of nursing routines, the notes on the patient's conditions were made quickly and incompletely, as well as the nursing process was incomplete and its evolution routine practically ignored.

In sectors where the nursing process were more advanced, there was a difficulty associated with lack of standard and the nursing professionals rotation who performed the patient records because of the work schedules and the consequent disruption in monitoring patients. In this sense, CNR4 and CNR7, in this order, stated:

'Often, I begin the duty, I establish my rules and then, at the time of the duty passage, often the colleague did not accept or it is missing something, he complained, isn't it?'.

'I see, I note toxicities, I record, but as it is in a medical record (-) and the latest evolution we have is that of the last professional who moved this chart, I miss the monitoring of mine.'

In addition, an important practice was the actions of health professionals in the IT area, since their knowledge about the care routines, convincing nursing professionals regarding the use of technology, as reported by SITM2 in his speech:

'We have to convince that it is good, you know? This becomes a bit tiring. Further, here at the hospital, it has improved considerably because we have health professionals working in the IT area, isn't it?'

According to the statements, it is clear that the institution had the following past practices: incomplete notes about the patient; habit to make quick notes; nursing process fragmentation; nursing process informality; not computerized nursing process; health professionals in the IT area; patient evolution routine ignored; and use of paper in formal care. These evidences were found in the speeches of eight interviewed managers, showing the standards of practice established in many sectors at the hospital. It is important to note that the module adoption can be interpreted based on these practices and its understanding can help reduce uncertainties associated with the adoption process of the module, because it cannot deal with an innovation except based on what is familiar (ROGERS, 1983).

At that time, the hospital's senior management was very open to receive technologies, highlighting the importance of management and assistance technologies investments, 
revealing itself an important aspect contained in the category of innovativeness, which is the degree to which an adoption unit is a pioneer in technology adoption (ROGERS, 1983).

Human resources did not have enough knowledge and experience about the nursing process, even because only recently, it was regulated through the Brazilian Federal Nursing Council Resolution No. 358, 2009, and many nurses have graduated recently. Some managers mentioned problems related to professional training and the need to assess their knowledge on this process. A pressing need was the staff training to deal with the nursing process.

Another problem perceived by managers is related to the large workload of the professionals involved in nursing routines, creating difficulties for carrying out all the records of the nursing process. Moreover, in some sectors the patient's length of stay was very brief, which further pressured the nursing routines, making it difficult to formalize. Ghodeswar and Janardan (2006) argue that hospitals need to consider the level of patient demand, which when high, it becomes a challenge to health professionals. This view is evident in the CNR3 speech:

'Every twenty minutes it changes the patient. Therefore, you have to do it all fast, but it changes not because they go away [the patients]. Most of them go to other sector, isn't it? To stay in hospital. So they need to fill it quickly'.

There is also a model centered in the medical, causing the perpetuation of a low valuation of the nursing process by the nursing teams themselves. The CNR1 said about it:

'The nursing staff is still very timid in this evaluation because of their $n$ activities within the clinic that involve the administration, supervision of nursing on the whole team, the sector organization... The assistance itself ends up being damaged and as (-) there is this culture focused on the doctor (...), even the nursing staff not valorizes so much the nursing prescription'.

In this previous moment, there was not adequate staff dimensioning in the sectors, since the organization was undergoing changes due to the Judgement TCU No. 1520, August 23, 2006. Since joining Ebserh in 2013, a public concourse was fulfilled and there were several candidates' convocations, replacing the 'precarious HUB employees'. In this sense, conflicts were occurring due to various co-existing employment relationships in the institution and some of the informal leaders have been replaced through the public concourse. This situation is associated with the category of organizational leadership needed to ensure strategic coherence of the organization (CRESSWELL; SHEIKH 2013).

Although they are hiring people who were entering the job market, there were some of the old professionals who had greater resistance to systematization. This was perceived, because the nursing prescription module was preceded by the adoption of a number of other modules. Moreover, with the public concourse and its convocations in 2013, the hospital received professionals from different Brazilian regions, establishing in the institution a wide range of knowledge and behaviors.

Respondents perceived that the hospital spent a long time stagnated in the technological area due to investment restrictions. When there was available budget, investments were directed to the IT infrastructure to allow the advancement of systematization at the hospital (from 2013, important advances have occurred with the incorporation of Intranet, exchange and acquisition of several computers, the introduction of a wireless local area network for enterprise access and visitors) and for the training of medical and healthcare networks, so they could work with the systems. These characteristics indicate the importance of available financial resources, identifying with the category availability of resources (RYE, KIMBERLY, 2007).

There are still a limited number of computers available for use by nurses in their units and a need for organization care management and lacked a tool to guarantee compliance with the nursing prescription process, directly benefiting patient safety, as said CNR5: 
'The need we always had, the need to have a computerized system'.

Incrementally, the respondents mentioned the need to expedite and promote the integration of the nursing process. Broadly, it is essential to change health professional behavior, leaving the focus on disease and incorporating the focus on the patient, and the development of the planning culture in the nursing professional's routines.

According to Rogers (1983), the felt needs and problems are a part of the characterization of the prior conditions that may lead to the adoption of an innovation. In this study, 18 items arising from statements were grouped as felt needs/problems, including knowledge and experience of professionals (DOSI, 1982), as well as process and human resources management. 12 managers interviewed realized these needs and problems.

Briefly, the reports about the planning culture incipiency; the low valuation of the nursing process by the nursing teams themselves; the dominant focus on disease; the regional diversity among hospital staff, resulting in different knowledge and behavior; the model centered on the figure of the doctor; and the resistance of some of the old employees, shape the norms of the social systems in force, prior to the beginning of the module adoption process at the hospital, involving the roles exercised by interest groups and the influences exerted by the professionals (ROGERS, 1983). Seven of the interviewed managers identified these issues.

Statements regarding restriction of technological infrastructure as well as the incipiency in information security at the hospital are associated with the category internal IT resources availability, which according Marsan and Paré (2013) are the information technology resources that the organization has at its disposal.

Table 5 summarizes the statements of managers, indicating which respondents made related statements, relating such statements to the categories defined a priori as well as indicating their references.

\section{CONCLUSIONS}

This paper is the result of an effort to outline a theoretical framework for the study of the diffusion of ICT in management and assistance services in healthcare. Besides that, this paper empirically verifies the applicability, at least in part, of the proposed framework for adoption of technology in this area, concerning the organizational drivers identified in the prior conditions in the case of technology adoption in a Brazilian public hospital.

The consolidation of the drivers in the framework (presented in the Table 4) made it possible to see that some of them like external pressure of the government, community interest in technology, government policy and social economic characteristics are not part of the internal environment of the adopting organization, but make up its macro environment, surpassing the level of the firm. Cresswell and Sheikh (2013) suggested the study of the environmental influences as a gap in the research on diffusion of innovation. Reflecting on the organizational perspective proposed by Bouwman et al. (2005) it is noticed that it is important to consider a new classification in coming studies, exogenous drivers.

Verifying the applicability of the framework concerning the prior conditions in adoption the nursing prescription module at the Hospital Universitário de Brasilia evidences eight organizational drivers among those 24 found in the literature and represented in the framework. It was found that the availably drivers of resources, felt needs / problems, innovativeness, internal IT resources, level of the patient demand, norms of the social systems, organizational leadership and previous practices intervened on the module adoption process. This does not mean that the other drivers of the prior conditions have not occurred, but simply that on the perception of the hospital managers the eight organizational drivers 
Table 5. Statements of manager's categorization considering prior conditions

\begin{tabular}{llll}
\hline Statements of managers & $\begin{array}{l}\text { Respondents who } \\
\text { mentioned }\end{array}$ & $\begin{array}{l}\text { Category defined } \\
\text { a priori }\end{array}$ & Referencies \\
\hline $\begin{array}{l}\text { Available budget } \\
\text { Investments in IT infrastructure }\end{array}$ & SITM2 & $\begin{array}{l}\text { Availability of } \\
\text { resources }\end{array}$ & $\begin{array}{l}\text { Rye and } \\
\text { Kimberly } \\
(2007)\end{array}$ \\
Investments in training teams & & & $(2007$ \\
\hline
\end{tabular}

Conflicts generated by the various Disorganization of the nursing care

Employment relationships in the hospital

Gaps in the education of nursing staff

Inadequate dimensioning of staff

Incipiency of nursing care control

Lack of experience of most newly hired nursing staff

Lack of knowledge about the nursing process

Lack of standardization of the nursing process

Need to evaluate the knowledge about the nursing process

SM1, SITM1, SITM2,

SM2, NR1, NR2, NR3, Felt needs/pro- Rogers

Need to integrate the nursing process

NR4, NR5, NR6, NR7， blems

(1983)

Need to speed up the nursing process

tool need to systematize the nursing process

Need to train professionals in nursing process

Replacement of precarious employees

Tracking difficulty and read the notes on the patient

Waste of time looking for records on paper

Work schedules and duties

Workload of nursing professionals

Devaluation of the nursing process by the nursing teams themselves

Dominant focus on disease

Model centered in medical

Regional diversity among hospital staff

SM1, SITM1, NR1, SM2, NR3, CCU1,

NR6

Norms of the

Rogers

social systems

(1983)

Resistance of the old employees

Habit to make quick notes

Health professionals in the IT area

Incomplete notes about the patient

Not computerized nursing process

Nursing process fragmentation

SM1, SITM1, SITM2,

NR5, CCU1, NR6,

Previous prac-

Rogers

Nursing process informality

NR7, NR8

tices

(1983)

Patient evolution routine ignored

Use of paper in formal care

Incipiency in information security

Restriction of technological infrastructure

SITM2, NR8

Internal IT

resources availability

Openness to incorporating technologies

SM1, SITM1

Innovativeness

Rogers (1983)

Patient's length of stay

NR3

Level of patient

Ghodeswar

demand dan (2006)

Replacement of informal leaders

SM1

Organizational leadership

Cresswell and Sheikh (2013) 
BBR

14,3 were more relevant in the process of adopting the technology in the managerial and assistance services. It is interesting to highlight that all the drivers indicated by Rogers (1983) in the previous conditions have been confirmed in this case study. These findings cannot be generalized.

For future research, it is relevant to verify the applicability of the organizational and individual drivers in the other stages of the proposed framework, as shown in Table 4 as well as in the prior conditions, either by new case studies or by developing quantitative research instruments. Moreover, it is important to observe that the list of drivers is very long. It is timely to discuss the relationships between all these drivers in order to reduce them to a complexity so they can be better understood.

\section{REFERENCES}

AGGELIDIS, V. P.; CHATZOGLOU, P. D. Using a modified technology acceptance model in hospitals. International Journal of Medical Informatics, v.78, n. 2, p. 115-126, 2009.

AJZEN, I. From Intentions to Actions: A Theory of Planned Behavior. In: Action Control: From Cognition to Behavior. J. Kuhl and J. Beckmann (Eds.). Springer Verlag, New York, p. 11-39, 1985.

AJZEN, I. The Theory of Planned Behavior. Organizational Behavior and Human Decision Processes, n. 50, p. 179-211, 1991.

AJZEN, I.; FISHBEIN, M. Attitudes and normative beliefs as drivers influencing behavioral intentions. Journal of Personality and Social Psychology,v. 21, n. 1, p. 1-9, 1972.

ALKRAIJI, A.; JACKSON, T.; MURRAY, I. Health data standards and adoption process Preliminary findings of a qualitative study in Saudi Arabia. Health Data Standards, v. 28, n. 5, p. 345-359, 2011.

BARDIN, L. Análise de Conteúdo. Tradução Luís Antero Reto e Augusto Pinheiro. São Paulo: Edições 70, 2011.

BARLOW, J. Strengthening the spread of innovation in the UK's National Health Service. In S. P. Osborne andL. Brow (ed.), Handbook of innovation in public services (p. 528-539).Edinburgh: Edward Elgar, 2013.

BAUER, M. W.; GASKELL, G. (Eds). Pesquisa Qualitativa com texto, imagem e som: um manual prático. Tradução de Pedrinho A. Guareschi. 7 ed. Petrópolis: Vozes, 2008, 516 p.

BOUWMAN, H.; HOOFF, B. VAN DEN; WIJNGAERT, L. VAN DE; DIJK, J. VAN. Information and Communication Technology in Organizations. London: Sage, 2005.

CHANG, I. C.; HWANG, H. G.; YEN, D. C.; LIAN, J. W. Critical drivers for adopting PACS in Taiwan: Views of radiology department directors. Decision Support Systems, v. 42, n. 2, p. 1042-1053, 2006.

CHEN, I. J.; YANG, K. F.; TANG, F. I.; HUANG, C. H.; YU, S. Applying the technology acceptance model to explore public health nurses' intentions towards web-based learning: A cross-sectional questionnaire survey. International Journal of Nursing Studies,v. 45, n. 6, p. 869-878, 2008.

CRESSWELL, K.; SHEIKH, A. Organizational issues in the implementation and adoption of health information technology innovations: An interpretative review. International Journal of Medical Informatics, v.82, n. 5, p.73-86, 2013.

DAVIS, F. D. Perceived usefulness, perceived ease of use, and user acceptance of Information Technology. MIS Quarterly,v. 13, n. 3, p. 319-340, 1989.

DAVIS, F. D. A Technology Acceptance Model for empirically testing new end-user information systems: Theory and results. 1986. 291 f. Tese (DoutoradoemAdministração) - Sloan School of Management, Massachussets Institute of Technology, Boston, 1986.

DAVIS, F. D.; BAGOZZI, R.P.; WARSHAW, P.R. User Acceptance of Computer Technology: A Comparison of Two Theoretical Models. Management Science, v. 35, n. 8, p. 982-1002, 1989.

DOSI, G. Technological paradigms and technological trajectories. Research Policy, n. 11, p. 147-162, 1982.

EMANI, S., YAMIN, C. K., PETERS, E., KARSON, A. S., LIPSITZ, S. R., WALD, J. S., WILLIAMS, D. H.; BATES, D. W. Patient Perceptions of a Personal Health Record: A Test of the Diffusion of Innovation Model. Journal of Medical Internet Research,v. 14, n. 6, p. 150, 2012.

FISHBEIN, M.; AJZEN, I. Belief, attitude, intention and behavior: An introduction to theory and research. Addison-Wesley, Reading, MA, 1975.

GHODESWAR, B. M.; VAIDYANATHAN, J. Adoption of medical technology by hospitals: a review of innovation attributes and a conceptual model of the resulting service. World Review of Science, Technology and Sustainable Development,v. 3, n. 4, p. 362-380, 2006. 
HOLDEN, R. J.; KARSH, B. T. A theoretical model of health information technology usage behaviour with implications for patient safety. Behaviour and Information Technology,v. 28, n. 1, p. 21-38, 2009.

. The Technology Acceptance Model: Its past and its future in health care. Journal of Biomedical Informatics, v. 43, n. 1, p. 159-172, 2010.

HUNG, S. Y.; HUNG, W. H.; TSAI, C. A.; JIANG, S. C. Critical drivers of hospital adoption on CRM system: Organizational and information system perspectives. Decision Support Systems, v. 48, n. 4, p. 592-603, 2010.

HUNG, S. Y.; TSAI, J. C. A.;CHUANG, C. C. Investigating primary health care nurses' intention to use information technology: An empirical study in Taiwan. Decision Support Systems, v. 57, p. 331-342, 2014.

KETIKIDIS, P.; DIMITROVSKI, T.; BATH, P. A. Acceptance of health information technology in health professionals: An application of the revised technology acceptance model. Health Informatics Journal,v. 18, n. 2, p. 124-134, 2012.

KIJSANAYOTIN, B.; PANNARUNOTHAI, S.; SPEEDIE, S. M. Drivers influencing health information technology adoption in Thailand's community health centers: Applying the UTAUT model. International Journal of Medical Informatics, v. 78, n. 6, p. 404-416, 2009.

KIM, S.; GARRISON, G. Understanding users' behaviors regarding supply chain technology: Determinants impacting the adoption and implementation of RFID technology in South Korea. International Journal of Information Management, v. 30, n. 5, p. 388-398, 2010.

KIM, J.; PARK, H. A. Development of a Health Information Technology Acceptance Model Using Consumers' Health Behavior Intention. Journal of Medical Internet Research,v. 14, n. 5, p. i36, 2012.

LAI, H. M.; LIN, I. C.; TSENG, L. T. High-Level Managers' Considerations for RFID Adoption in Hospitals: An Empirical Study in Taiwan. Journalof Medical Systems, v. 38, n. 2, p. 1-17, 2014.

LATOUR, B. Ciência em Ação: como seguir cientistas e engenheiros sociedade afora.São Paulo: Editora UNESP, 2000.

LIN, C.; LIN, I. C.;ROAN, J.Barriers to Physicians' Adoption of Healthcare Information Technology: An Empirical Study on Multiple Hospitals. Journal of Medical Systems, v. 36, n. 3, p. 1965-1977, 2012.

MARSAN, J.; PARÉ, G. Antecedents of open source software adoption in health careorganizations: A qualitative survey of experts in Canada. International Journal of Medical Informatics, v. 82, n. 8, p. 731-741, 2013.

PARASURAMAN,A.; COLBY, C. Techno-ready marketing: How and why your customers adopt technology. New York: The Free Press, 2001.

RATCHFORD, M.; BARNHART, M. Development and validation of the technology adoption propensity (TAP) index. Journal of Business Research,v. 65, n. 8, p. 1209-1215, 2012.

ROGERS, E. M. Diffusion of innovations. New York: The Free Press, 1983.

RYE, C. B.; KIMBERLY, J. R. The Adoption of Innovations by Provider Organizations in Health Care. Medical Care Research and Review, v. 64, n. 3, p. 235-278, 2007.

THOMPSON, T. G.; BRAILER, D. J. The Decade of Health Informaton Technology: Delivering ConsumerCentric and informaton-Rich Health Care: Framework for Strategic Action. Washington, DC: US Department of Health and Human Services, 2004.

VASILEIOU, K.; BARNETT, J.; YOUNG, T. The Production and Use of Evidence in Health Care Service Innovation: A Qualitative Study. Evaluation and the Health Professions, v. 36, n. 1, p. 95-105, 2012.

VENKATESH, V.; DAVIS, F. D. Theoretical extension of the technology acceptance model: four longitudinal field studies. Management Science,v. 46, n. 2, p. 186-204, 2000.

VENKATESH, V.; MORRIS, M. G.; DAVIS, G. B.; DAVIS, F. D. User acceptance of information technology: toward a unified view. MIS Quarterly,v. 27, n. 3, p. 425-478, 2003.

VENKATESH, V.; THONG, J. Y. L.; XU, X. Consumer Acceptance and use of information technology: extending the Unified Theory of Acceptance and Use of Technology. MIS Quarterly,v. 36, n. 1, p. 157-178, 2012.

WARD, R.; STEVENS, C.; BRENTNALL, P.; BRIDDON, J. The attitudes of Healthcare staff to IT: a comprehensive review of the research literature. Health Information and Libraries Journal,v. 25 , n. 2, p. 81-97, 2007. 